\title{
FORTY-SEVEN DJS, FOUR WOMEN: Meritocracy, Talent and Postfeminist Politics
}

\author{
$\because$ Feature Article $\longrightarrow$ \\ TAMI GADIR \\ UNIVERSITY OF OSLO (NORWAY)
}

\begin{abstract}
In 2016, only four of forty-seven DJs booked for Musikkfest, a festival in Oslo, Norway, were women. Following this, a local DJ published an objection to this imbalance in a local arts and entertainment magazine. Her editorial provoked booking agents to defend their position on the grounds that they prioritise skill and talent when booking DJs, and by implication, that they do not prioritise equality. The booking agents' responses, on social media and in interviews I conducted, highlight their perpetuation of a status quo in dance music cultures where men disproportionately dominate the role of DJing. Labour laws do not align with this cultural attitude: gender equality legislation in Norway's recent history contrasts the postfeminist attitudes expressed by dance music's cultural intermediaries such as DJs and booking agents. The Musikkfest case ultimately shows that gender politics in dance music cultures do not necessarily correspond to dance music's historical associations with egalitarianism.
\end{abstract}

KEYWORDS: dance music; DJ; gender; politics; postfeminism

TAMI GADIR is a postdoctoral researcher at the University of Oslo, Norway. Her current project (2015-2018) addresses gender in dance music culture, focusing on the experiences of DJs. This research has been published in a special issue of the Contemporary Music Review on "Gender, Creativity and Education in Digital Musics and Sound Art" (2016) and in the Routledge Research Companion to Popular Music and Gender (2017). Both DJing and clubbing are central to her research. <tami.gadir@imv.uio.no>

Dancecult: Journal of Electronic Dance Music Culture 9(1): 50-72 ISSN 1947-5403 @2017 Dancecult http://dj.dancecult.net http://dx.doi.org/10.12801/1947-5403.2017.09.01.03 


\section{INTRODUCTION}

It's not about gender. It's not about gender. It's about being good or not. And you're playing because you're a good DJ, not because you're a girl. Most of the times. I see some bookings, they book because you're a girl as well, but probably because you are a good girl. ${ }^{1}$

Musikkfest is an annual, multigenre music festival in Oslo, Norway. In the lead-up to the 2016 festival, a DJ and editor of a local arts and entertainment magazine, Natte $\sim$ Dag, noted that, of the total number of DJs booked for the event (forty-seven), only four were women. The Natt\&Dag editorial (Furuseth 2016), entitled "Forty-Seven Artists, Four Women", critiqued this imbalance. Subsequently, the festival's booking agents engaged in a heated debate about what they referred to as "political correctness" with DJs and fans on social media. To investigate these perspectives further, I held a group interview with five Oslo DJs; two were booking agents for Musikkfest, and one was among the four women booked to DJ for the festival. The interview revealed strong beliefs in "hard work", "skill" and "talent" as the combined means to a successful DJing career. The booking agents, supported by the DJ who was booked for the festival, also maintained that gender bias is an overstated issue that does not factor into their bookings. ${ }^{2}$

The debate is a resounding example of the discourses of art worlds that champion art's supposed ability to supersede inequalities or render such inequalities irrelevant. Such a perceived irrelevance is buttressed by the fluid, unregulated work practices and informal social connections that commonly characterise "creative industries", the encompassing label for these art worlds in policy (Frith 2011: 62; Reitsamer 2011: 30-1; Conor et al. 2015). And it is precisely because creative industries are informally organised and unregulated that cultural intermediaries (in this case, booking agents) are not held to account for unequal hiring practices and other forms of discrimination.

The same intermediaries intertwine this idea-that the aesthetic qualities of art reign supreme over concerns about equality-with a neoliberal narrative of individualism comprised of postfeminism, meritocracy and talent. Postfeminists hold that the work of feminism is complete, and no longer has a purpose. ${ }^{3}$ In other words, they espouse the view that we are living in an era in which women have as much agency as men, and gender identity concerns are outdated. Scholars have increasingly identified and critiqued this perspective as it has manifested across the West since the 1990s, as well as its prevalence in cultural policy and media (Modleski 1991; Brooks 1997; McRobbie 2004, 2009; Gill 2007, 2016; Conor et al. 2015). For Rosalind Gill, a stark example of the link between postfeminism and neoliberal, individualist ideals is the bodily self-policing that many women practise, and the packaging of such self-policing as a choice or method of empowerment (Gill 2016: 613). The Musikkfest booking agents are postfeminist in their opposition to an emphasis-in the media, within musical communities, in political rhetoric, in law-on quantitative gender equality. ${ }^{4}$ What is more, when they express their objections to the types of gender equality concerns articulated in the Natte Dag editorial, they feel silenced and accused unfairly of political incorrectness by their dance music scene peers. 
It is striking that such perspectives prevail even in Norway, often cited in media and popular discourse as "one of the best countries in the world to be a woman" (Dowling 2010; The Economist 2016). ${ }^{5}$ Indeed, in informal conversations I have had about my research in Oslo, Norwegian-born men in their twenties have commonly protested, "but there are no gender issues in Norway". The laws that have governed Norway's equality and diversity hiring practices in recent history constitute a possible explanation for the strength of this type of postfeminist discourse. One such law is the Gender Equality Act (1978), which is at the centre of policies that govern Norwegian working and domestic life. Together with other policies that include affirmative action for women on corporate boards and gender self-determination legislation, it has helped to inform the contemporary, mainstream cultural paradigm of gender equality in Norway. This normalisation has led to those who believe in "quality" over equality to believe that they are going against the grain of popular cultural discourse. However, the audibility of the Musikkfest booking agents' postfeminist perspectives suggests the opposite: that cultural attitudes toward equality, such as they are expressed in dance music scenes, do not necessarily correspond to what is happening in law. Ultimately, the Musikkfest case shows that gender politics in dance music cultures are out of sync with the egalitarian discourses expressed in scholarly histories and ethnographies of dance music. ${ }^{6}$

\section{Gender in Norway}

Norway has an international reputation, along with other Nordic countries (Denmark, Finland, Iceland, Sweden), as having among the world's best records of gender equality (Niskanen 2011: 11; The Economist 2016). As historian Kirsti Niskanen notes, gender equality is one aspect of the social democratic political philosophy that underlies many policies in Nordic countries, with the workplace as a key site for implementation (2011:11). Indeed, there is evidence of gender equality discourse becoming normalised as early as the 1920 s and '30s in Norway's print media, when women began to participate as equals in civic society through such moves as gaining the right to vote, accessing higher education and organising themselves institutionally and politically (Larsen 1927; Dagbladet 1929; Fearnley 1930; Stenhamar 1932; Lindbæk 1936). The fact that these discussions took place in the public sphere reflect the strength and momentum of the ideal of equality for all citizens (see Dahlerup 2011; Niskanen 2011; Teigen 2011). ${ }^{7}$

In the late $20^{\text {th }}$ century, a core policy that anchored this change in work environments was the Gender Equality Act, originally instated in the Norwegian parliament in 1978 (see Teigen 2011: 88; Gender in Norway 2016). The Act contains clauses that compel government institutions to ensure that female and male genders are represented equally on "committees, governing boards, councils, delegations, etc." through strict rules of ratio (government.no 2007). Furthermore, it instructs employers to "make active, targeted and systematic efforts" to pursue gender equality, rendering any "discrimination on the basis of gender" illegal. "Direct differential treatment" means that "a person is treated worse than others in the same situation, and that is due to gender", while "indirect differential treatment" 
means that "any apparently neutral provision, condition, practice, act or omission that results in persons being put in a worse position than others, and that occurs on the basis of gender" (government.no 2007). Following its institutional implementation, a cultural normalisation of the goals of such legislation gradually occurred, though it was met with resistance at every step. In the early 2000s, for example, board executives expressed concerns that positive discrimination towards women on corporate boards would result in better qualified male applicants being overlooked (Dowling 2010) and compromise the freedom of choice of managers (Teigen 2011:88).

In the early $21^{\text {st }}$ century, measurable gender equality policies have been internalised and integrated into the mainstream; Norway's Conservative Party, Høyre, is among the parties that support such initiatives (Dowling 2010; Høyre 2017: 36-7, 84, 89-90; Teigen 2011: 88). Another example of this "evolution" of gender policies is the 2016 legislation that allows people the freedom to identify as female or male regardless of their biological or birth designations (Hartline, forthcoming; Thommessen 2015-2016; Ministry of Health and Care Services 2015-2016; van der Ros 2017). The human rights policies of the current Norwegian government promotes equality for all genders, ethnicities, sexualities, ages and abilities (Høyre 2017: 36) and the Constitution contains the statement, "All people are equal under the law" (Stortinget 2016a). Yet some scholars argue that the belief in (and cultural support for) equality is not in popular discourse in the same way for non-white ethnic minorities as it is for marginalised genders. Specifically, people of colour and of nonwestern backgrounds have not yet been effectively incorporated into a widely-accepted, state-endorsed cultural definition of Nordic social democracy (Svendsen 2017). Instead, in an echo of populist politics in other Western European countries, the gender equality ideal is commonly conflated with ideas that equate white Nordicness with progressive politics and non-white, non-Nordicness with gender oppression-in effect, a form of white nationalism (see also Butler 2008; Mepschen et al. 2010; Svendsen 2017).

\section{Flexible on Work, Flexible on Equality}

While the Norwegian national goal of gender equality has concrete and visible effects in formal organisations, such as strict gender ratios in hiring policies, there is a large disparity between gender ratios in public and private sectors. Specifically, women occupy $70.4 \%$ of public sector jobs, and only 36.6\% of private sector jobs (Stovik in Dowling 2010; Statistics Norway 2014). As in other countries, nightclub managers, promoters, booking agents and DJs-as entrepreneurs in the private sector-are often self-employed and contracted to jobs on an ad hoc basis. This is an example of how nightlife scenes and other types of art worlds driven by informal networks are exempt from accountability on implementing equality policies. This lack of accountability is a characteristic feature of the "flexible" work world of DJs everywhere, and Norway is no exception. It is precarious, and people's livelihoods depend on the whim of other players-booking agents, promoters, label owners and club managers (Reitsamer 2011). In contrast to social services departments or public health systems, the DJ's working environment is not publicly regulated, is characteristically informal, unpredictable, 
cash-driven, devoid of official paperwork or organised representation and intertwined with networks that are under the radar of the law (Reitsamer 2011). ${ }^{8}$ DJs are frequently sole traders, thereby not falling within the category of employment that safeguard the rights of other staff at the same events (such as bartenders). Consequently, if women experience discrimination, there are no systems in place to protect them-they have no formal method of complaint and no one to complain to. As Conor, Gill and Taylor argue (2015), where work is competitive and limited, women and people of colour are particularly susceptible to discrimination. Norwegian cultural commentator Joachim Lund notes that "culture is a self-referential universe ... the rules and mechanisms valid for the rest of the world do not have validity here" (2012: 6). In other words, culture is supposed to float above or beyond gender and other identity groupings - a prevalent postfeminist sensibility in the culture industries. Unless directly challenged, this leads to the persistence of discrimination.

Indeed, together with the aforementioned prevalence of racial prejudice in mainstream discourse, such a conception of culture also affects participants of colour. For example, in a 2015 interview, a white booking agent and DJ in Oslo explained to me that a venue hired her to diversify the genre profile of the club-namely, to steer the music away from hip hop. ${ }^{9}$ She linked this to the club's reputation as a hub "where most of the drug dealing Africans hang out". This had previously been used by local authorities as a rationale for closing down other hip hop venues, which had been popular among local communities of colour. I asked the agent why authorities do not also crack down on the primarily white night clubs for parallel drug dealing practices. She stated that "these people tend to be rude to the staff... And a bit touchy." Yet this reasoning — drug dealing, rudeness and harassment-is dubious. There is no shortage of white men who deal drugs, are rude to staff, and physically harass women of all backgrounds. The decisions of local authorities, and the subsequent practices of venue managers and booking agents, appear instead to be tied to problematic attitudes about race and its intersections with class: venues that host better-off, white clubbers are allowed to do as they wish. The Musikkfest case in this article is made up of white DJs and booking agents who perform and book DJs mostly at the latter venues. Given that they benefit from being part of a dominant and normalised majority identity group, it is unsurprising that they do not raise the matter of race.

Dance music participants and commentators around the world have challenged the problematic practices of gender and racial discrimination in their scenes. There are numerous examples that appear in media from 2015 and 2016 alone (see Matos 2015a, 2015b; Hubbell 2016; Lal 2016; Loben 2016; Mitchell 2016; Resident Advisor 2016; Thump 2016; Weiner 2016). Moreover, Norwegian contemporary media, especially mainstream and local newspapers, cover discussions about gender and music industries in numerous editorials and commentaries that include statistics and debates. Issues in music that they address range from the programming of the Oslo Philharmonic (Kvalbein 2013:7) to the percentage of women on stage at Øya, a popular music festival (Lund 2011: 12; Asker 2015: 9). One article cites international coverage of Norway for how it meets gender quotas in the music festival scene more effectively than in other countries (Woldsdal 2015). Nonetheless, as the below case of Musikkfest illustrates (Furuseth 2016), when people complain about gender discrimination 
in art worlds that are built on informal networks, key players in these networks still react negatively. Thus, the ostensible mainstreaming of gender equality language in national politics and media still faces vocal resistance.

Together, most of the aforementioned media coverage and public discussions are based on the idea that "equality" means measurable ratios of women to men. This neither addresses how gender informs people's behaviours, nor acknowledges the experiences of gender non-conforming, genderqueer, or transgender people at all, despite the recent legislation that ostensibly espouses more open understandings of gender (Thommessen 2015-2016; Ministry of Health and Care Services 2015-2016; Stortinget 2016b). ${ }^{10}$ Certainly, the promotion of gender equality through numbers can now be characterised as a prominent, even dominant position on gender issues in some of the widely read newspapers and through the main public broadcaster in Norway, the NRK. ${ }^{11}$ Yet it is in the meeting of these media voices with gender prejudices that persist in everyday life-through popular culture and postfeminist discourse - where this increased gender consciousness causes discontentment.

\section{Club Cultures and Personal Politics}

In this section, I will discuss the case of Musikkfest Oslo-a free, multigenre music festival, inspired by the French Fête de la Musique (National Music Day). The festival has run since 1992 as a public initiative of the City of Oslo with the cooperation of public venues and spaces (Bjørhovde 2015). In 2016, DJs performed both within the official Musikkfest program and as part of the afterparties in local nightclubs. Of the forty-seven DJs booked for the 2016 event, four were women. Before the festival, a DJ and music editor, Karima Furuseth (2016), commented on this disproportionately male majority in a music magazine, Natt\&Dag, through her article, 47 artister, fire kvinner (“47 artists, four women”). Her editorial provoked impassioned reactions from dance music participants of all genders, and the debate that followed brought issues of gender discrimination to the fore. Some participants proceeded to protest through what I have called an "anti-party" of DJs who were exclusively women. At the same time, booking agents asserted that they felt unfairly accused of sexism.

I attended the anti-party, and later conducted two group interviews with DJs and booking agents-one with five participants and one with two. In total, I asked fifteen people (DJs and booking agents) for a group interview. Seven agreed to talk, and two were split from the remaining five to accommodate their schedules. The participants were involved in various ways in Musikkfest and the anti-party, and were therefore well-placed to present a range of perspectives on the controversy. The material that I use henceforth is based on the first group interview with five participants. ${ }^{12}$ All five participants have played both the roles of DJs and booking agents during their careers. I had seen all five participants DJ between 2015 and the interview, and had attended club nights promoted by three of them.

In the interview material below, Hans, Lars and initially Dani, contend that the Natt $2 D a g$ article is one-sided, simplistic and disingenuous. These and other specifics are subsumed within two overarching themes, central to their claims throughout the interview: first, that any engagement with the topic of gender balance that does not come down on the 
side of booking more women leads to (unfair) accusations of political incorrectness; and second, that gender balance moves the focus away from the quality of the job (merit of the performer). The first point is made by a booking agent, Hans:

Hans: Last year, $90 \%$ of the DJ line-up at Musikkfest was female, so we've had a lot of the girls already, so it [didn't feel] natural to do it again. I think the programming aspect of the whole thing has been left out. I think it's left out that a lot of our culture's based on community... We felt that the criticism... was wrong, and came from someone who has benefitted from being part of that community. And she also has, of course... her own agenda, and it's a good thing-but we felt that we couldn't speak out because it would be politically incorrect to say something, or criticise or comment on it. I guess this is the core of the problem: that we don't feel like we're either leaving the girls out or not thinking about them or not booking them. We feel like we actually make an effort, booking female DJs throughout the year. But you have to look at the ratio between how many female DJs you have, and you have to compare the guys. You have to consider that these girls aren't always available; that's left out of this discussion... How a DJ plays is left out of the discussion. And... I didn't feel like taking part in this discussion because everything I said would have been conceived as politically incorrect.

\section{Tami: In what sense politically incorrect?}

Hans: That if you criticise... it's always going to come back to, "okay, not booking enough girls. You should have had girls... at that event. You should have had more girls at [club] throughout the year. But there's [sic] so many people who speak in this discussion who don't know how the booking industry works, which means it's very difficult to discuss this... you always end up discussing it on very different terms.

Here, Hans not only objects to what he perceives as an omission of relevant information from the article, but articulates a frustration with criticisms of gender ratios in DJ bookings - on the basis that they misunderstand the industry. Furthermore, he argues that Furuseth should not critique her "community", where community is implied as a collective description of Oslo's dance music participants. Lastly, he points to "how a DJ plays" as a factor excluded from the article. This thread is taken up later in the interview, when Hans states that he only chooses DJs for their talent (not their gender). The second male booking agent, Lars, argues in parallel that hard work such as networking (not gender) leads to gigs. As I will show in the next section, the necessarily gendered nature of networking is overlooked, and "hard work" and "talent" constitute a strong postfeminist dual narrative throughout the interview.

The politics of the Natt Dag author and the booking agents are entangled with a longer history of a dance music community in which most people know each other both professionally and personally. There is little room for detail in the short article, and some women had indeed turned down Musikkfest invitations because of previous commitments. 
It is also reasonable that any journalistic account that critiques the actions of others should be fact-checked. In this sense, the booking agents are reasonable in their objections. I wish to complicate and contest their overarching contention, though, that merit should take precedence over gender parity. ${ }^{13}$

\section{Merit (and its Gendering)}

At first glance, the elevation of merit seems an innocent and reasonable contestation against affirmative action. Why, indeed, should an artist be booked "just because she is a woman"? Dani agrees with this sentiment, partly because she was one of the four women booked to DJ at Musikkfest. As such, she takes the criticism of the festival's gender balance as a personal affront to her skills:

Dani: For me it was an attack on a lot of us... and I didn't think it was fair... If you want to be represented in what you're doing... being a female... yes, it is unfair: this is a lot more ratio of men to women; we are not listed on "Top $100 \mathrm{DJs}$ ", possibly. But my agenda is: "work harder, be heard", and that's what it's about. It's not about "man versus female" or "female versus man", and I don't wanna be booked just because I'm a girl. And I'm starting to notice that's kind of happening... that I'm being put together with Ellen Allien or Miss Kittin or whoever, not for my merit and what I do, but because I am a woman... I think it's a weird topic, and I feel both sides by being a female, but I also understand, you can't just book women because they're women. And to build a balance about it, you need to actually be a great DJ.

Dani's perspective thus fluctuates between frustration with being branded as a woman when being booked for gigs with women headline acts on the one hand, and being discriminated against for being a woman on the other: $:^{14}$

Dani: Publications need to talk about what [female musicians] are actually doing, instead of what they're wearing or what they look like or who they're dating... I mean, even look at Nina Kraviz: she still gets every article mention, pretty much, [because] she was together with Ben Klock, you know... Which is probably how she did get where she is.

Dani views well-known DJ Nina Kraviz simultaneously as an unfair target of unfair media representations, and as a DJ who benefited from her relationship with a prolific male DJ. Thus, on the one hand, Dani identifies with women's struggles and frustrations, and on the other, she aligns with the meritocratic arguments put forth by Hans and Lars. ${ }^{15}$

In contrast to perspectives that intersect with the aforementioned postfeminist sensibilities, women are subject to judgements of their merit based on a range of criteria. And while some of these are the same as the criteria used to judge their male counterparts; others are markedly different, such as expectations of how they should present. Scholars have addressed and challenged this along with other disparities on the basis that they are informed by limited, binary conceptions of gender (Farrugia 2012; Gavanas and Reitsamer 2013; Gadir 2016, 2017). Nevertheless, the apparently gender neutral ideal of meritocracy 
fits into neoliberal paradigms that emphasise how individual hard work is rewarded, no matter what. The fact that scores of people are excluded at the outset due to sexism, racism, ableism, classism, ageism and more, is glossed over by the positive terms of this ideology ("work hard, succeed"). As Lars said:

Lars: Stand in the door, do decorations, hand out flyers, promote... I did that for five years before I got even a gig. I was... running around with crates of beer for all the party promoters... you have to make a choice, and be poor for several years... before you can make a living out of it... now I'm making money, but the first ten years I didn't make shit. I hustled and I sold clothes and I sold stuff-I was a small-time gangster... And I guess you have to make a few tough choices regarding that, and for a few people they need to bite the apple and take a job instead... in order to survive. ${ }^{16}$

Hans proceeded to observe how such risk-taking may be gendered:

Hans: You see people who are really, really thorough-who work, work, work-they succeed. And I'm not saying that girls don't, but... I think there's [sic] more guys who dare to take a chance and live off nothing for ten years than girls.

Hans acknowledges the disparities of risk between the genders without accounting for them, while Lars focuses on what he calls the relative "interest" of men and women:

Lars: There's always been quite a few females on the scene... I remember going on a national tour with [name] back in '96, and we brought [name] onto national radio in '98, so there's always been talent about... and even to look up to, I guess. But obviously not enough, but I don't think that has to do with the male DJs, probably... The lack of female DJs doesn't necessarily have to do with the $80 \%$ of male DJs... It might have to do with interest.

\section{Tami: In what way, because you've said this "interest" thing a few times?}

Lars: About spending enough time with the craftsmanship and with music.

Here, Lars deflects responsibility from male DJs for lower numbers of women, to a comparable lack of commitment by women to the labour-intensive pursuit of DJing. He continues in this vein when discussing what he implies is an obsessive hobby of record collecting:

Lars: When I was a kid, growing up, buying records, starting into this culture, I always saw one or two girls in the record stores.

\section{Tami: Out of how many people?}

Lars: Let's say if there were 20 guys digging for the same imports, there were one or two girls there. And they often came too late to get the imports, probably because they didn't have time or they didn't have enough interest. But those who were around... spent time, and they were good enough and started to DJ. I guess it probably has to do 
with the nerd factor of it as well, about spending so much time and being so interested in getting that music and being involved in the scene, and spending those hours in order to understand it and dig it. And it takes up all your time when you're a kid. And I guess for a girl who's $15,16,17$, probably she has other interests, more often than guys, regarding digging deep into a certain type of music style. You can see that when you look at [name], which is like a local band music competition for kids, $80 \%$ are guys, performing their music, and it's $20 \%$ girls. And I guess that has to do with how culture is. I don't know. How females wanna spend their time, you know?

In this account, women are less likely to be "nerds", and girls of 15-17 are less likely to be interested in the pursuit. ${ }^{17}$ For a moment, Lars suggests that cultural factors could be at play, but he subsequently returns to choice: girls do not want to spend their time collecting records.

Claims about the lack of interest of women in the obsessive pursuit of recorded music has a history across musical genres. The fetishisation of the material artefact, more than simply a means to playing back recorded sound, has been identified by Will Straw as a marker of masculinity-reinforced by understandings of record collecting as a mode of expertise (1997: 4-5), and in Sarah Thornton's terminology, of subcultural capital (1995: 60-1). This "mastery" excludes women due to a process of male "homosociality"realms of socialisation where men are the sole bearers and sharers of their "nerdish" obsessions (Straw 1997: 7-9). Indeed, the rarer the records are, and the more they cater to the tastes of niche, genre-focused musical communities, the more women are denied access (Leonard 2007: 46-7; Straw 1997: 11-12).

The "work hard, be heard" narrative is powerful. However, as Hans speculates, such unpredictable work is not possible for everyone. The first people to stop working in such jobs come from socio-economic disadvantage, often including women and people of colour (Conor et al. 2015). In addition, in nightclub work, the means to achieving both creative artistry and entrepreneurship are informed by gender (Reitsamer 2011:36-9). To take the most obvious example, women's bodies in a neoliberal, postfeminist lens are policed (by themselves and by others) and closely maintained through "beauty" treatments and other modifications (Gill 2007: 149). Ageism is also built into such gender disciplining-namely, the "expiry date" imposed on women. High profile male DJs, producers, promoters and record label owners are increasingly revered as they age. Yet despite the presence of highprofile women in dance music in their forties and beyond making inroads in the industry, older women who DJ are still not the idealised norm. The youthful female still dominates neoliberal marketing imagery-imagery that matters inasmuch as DJing is performance and the DJ is to-be-looked-at. ${ }^{18}$ This type of bodily disciplining is integral to the neoliberal female subject's individual "hard work" ethic. Although this generally remains unsaid, it is evident across dance music industries (Farrugia 2012; Gavanas and Reitsamer 2013).

In addition, many women I have interviewed have expressed that networking is more difficult for them, due to what Reitsamer's participants describe as "male networks" (2011: 33; see also Farrugia 2010: 89). Indeed, in this group interview, Lill and Dani began to talk more freely about their impression of a "boys' club" after Hans and Lars had left. This 
might be symptomatic of their sense of vulnerability to the whim of booking agents- that disagreeing with them could have negative consequences for their careers. Whether or not this is the case, the formal interview's epilogue was every bit as revealing as the initial interview where all five participants were present: ${ }^{19}$

Lill: Why can't we say this when the guys are here? Why are we holding back on these comments?

Dani: I didn't really think about it till now.

Lill: When they say: "You need to go down to the club and hang out and get to know people" - that's a boys' club; there's no girls in that club. And you don't get invited... what they're saying, in between the lines, is basically that "we book on talent", that "we book more guys than girls". And what I'm hearing is that there isn't enough good girls.

Dani: Yeah, that's what they're saying, yeah.

Lill: But they would never admit that. But that's what they think. And they think that based on their completely subjective opinion-because they are so geeky about production and technical abilities. ${ }^{20}$

\section{Tami: But why didn't you think you could say all this stuff in front of Hans and Lars?}

Lill: Oh, I've had this conversation with Hans so many times.

Dani: Lars was very dominating in the conversation.

Lill: Yeah, I got thrown off by that comment. Like, he comes in and he talks about his long experience rather than the actual issue at hand, which, I just thought there was no getting anywhere here, anyway... 'Cause he kept bringing up, you know: "If you wanna make it, you have to do this full-time and put your heart and soul into it". And I tried vaguely to say: "But... fair enough, there is [sic] loads of full-time DJs in Oslo, but there is [sic] also loads of non-full-time DJs. Both guys and girls-and the guys get booked more than the girls". So, if we can look at it from that perspective, and not: "girls aren't putting enough into it".

The notions of meritocracy that the booking agents articulate rest on two main problematic assumptions. The first is that anyone who works hard enough can succeed regardless of gender. On the contrary, it is less easy for a group that has been historically and systematically excluded from a community to compete for the first time with those who make up the vast majority of that community (Conor et al. 2015). That is, the ostensibly objective judgment of the worth of women does not, in practice, take place on an equal footing to the allegedly objective judgment of men's worth, particularly in environments that have long been male-dominated. The second false assumption is that the milieu is a neutral space in which the promoters and booking agents who curate DJs for club nights make 
such decisions objectively; that they base their choices exclusively on performers' skills, the quality of their mixing and their track choices. This space is not gender neutral; dance music environments are frequently gender unequal by default (like other environments), and those that are not, are exceptional (Gadir 2016). This gendering is so normalised that it is often invisible to participants. One such example is the understanding of DJs as male by default. In many dance music communities, it is a common experience for women to have difficulty convincing club security that they are there for DJing work, not to simply "jump the queue" as a clubber. Even once inside clubs, many women are presumed to be in attendance only to assist or support their partners (who are presumed to be male). Furthermore, DJs are asked to play on a variety of grounds, including those other than the music that they play: friendship; agreements ("if you book me for a gig at your club night, I'll book you at mine"); loyalty; group musical tastes; sexual relationships; and innumerable other factors. In other words, the whim of booking agents and promoters plays a significant role in DJ bookings. ${ }^{21}$ Thus, arguments that selection is an objective process do not stand up as justifications for women's underrepresentation.

\section{TALENT (AND ITS Gendering)}

In music pedagogical and psychological fields, talent appears to be discussed as ability that pre-exists effort or work (see Weinberger 2001). It is also sometimes described through terms such as "innate" (Helding 2011; Howe, Davidson and Sloboda 1998: 399-400). In both neuroscience and psychology, ideas about musical talent are further complicated. Scholars such as Hambrick and Tucker-Drobb (2014) and Mosing et al. (2014: 1800-2), for example, argue that a mix between genetic and environmental factors affect a person's capacity to realise talent (see also Stetka 2014). Similarly, neuroscientist Gary Marcus' (2012) popular science book on musical learning distinguishes between "music instinct" (a myth) on the one hand and other types of "talent" (a valid concept), on the other (Marcus 2012: 9).

In the interview with Musikkfest booking agents and DJs, the theme of talent emerged interchangeably with merit:

Tami: I asked you [earlier], "in your scene, is it just about talent when people get booked?", and you said "yes". But previously, you said that you have to be "bustling", or... on the door, or be active in the scene.

Lars: Well, you have to spend time in the scene, I guess.

Tami: Okay, so that's not just based on talent, then, right?

Lars: No, it's based on being interested-showing interest as well, of course, yeah.

Here Lars again raises the element of "interest" that DJs must show in order to secure bookings. This emphasis between two seemingly opposing concepts-hard work and "networking" on the one hand and talent on the other-has an internal logic. They are, after all, constituents of the same narrative: the brilliant and inspired yet struggling artist, 
who tirelessly and obsessively works at their art. This depiction fits into a distinctive, contemporary version of Romanticism that relates to neoliberal ideals of individual selfdetermination (Gill 2007, 2016; Frith 2011: 62-3; Reitsamer 2011). In this framework, an individual "with talent" can defy structural barriers such as class, race, gender, age and sexuality if they only work hard enough. Ideas about talent and of the different though related notions of creativity in western musical communities are not just Romantic, but also neoliberal: they elevate "a particular sense of selfhood and the valorization of the new" (Frith 2011: 70).

During the interview, the meaning of merit was expressed concretely from the outset. However, there was no clarity on what "talent" should mean, and I asked those left (all but Lars) to explain how they understood it. Their responses were revealing:

Dani: Quality of track selection, how you mix that track section... reading a crowd...

Hans: Researching the club.

Dani: That too, yeah. And just having tracks that are new, but also can be combined with old. I hate when DJs play just straight up classics and stuff like that.

Lill: I think it's very difficult to answer, because it's so situational... Sometimes I appreciate someone who's good technically... and that a night flows naturally.

Dani: I know for me it's engagement with the DJ and audience.

Hans: One thing is what you perform at the club, but if you're a shitty person and just a generally bad guy or girl, you're not going to get booked again. So being professionalfrom the moment you... set your foot inside a club, until you leave-is also a big, big aspect of it. Because promoters... talk to each other, and a lot of... people also want to come back if they have a good night... I think Dani summed it up pretty well, because it's about production talent and it's about how you perform at the club. You have to know that playing from 12 'til 3 or 1 'til 3 in Norway is very different from playing 1 'til 3 in Germany. So, it's about research, it's about... looking who played there the last weekend-should you have a chat with that person, maybe, just to hear how it was? What worked, what didn't work? How can you fit your style into that? Again, because style is... personal... but it's still the interaction with the people-and how you see them moving, how you actually look them in the eyes, be present when you're there-that's very important, I think. 'Cause there's [sic] so many good DJs with good track selection. But it's the flow, it's the groove, it's the presence.

Lill: It's so subjective, music. You have to be able to communicate that with the dance floor.

Sylvi: It's both about being technically good and building and getting the floor to dance and... communicating with people, you know, in a musical way. I think that's talent. 
Interestingly, all the interviewees seem to agree that the elusive "flow", "groove", "presence" and "musicality" are learned skills. Perhaps the idea of the "born artist" is relegated more to western classical or art musics than dance musics. This could partly explain the interchangeability of "hard work" with "talent" in these conversations. Regardless, these participants show how fluid and plural the term "talent" is. For DJs, it can mean: collecting "quality" music; technical ability on DJ equipment; familiarity with an audience; responsiveness to clubbers' feedback; the right mix of old with new music; an understanding of the temporal specificities of club nights; willingness to receive constructive feedback; showing understanding of genre; being "weird"; behaving "professionally"; communicating with clubbers; the capacity to "flow", "groove" and be present; and making people dance. In short, for these participants, "talent" equates to a DJ being good at their job, and gender, according to the booking agents, does not factor into how they evaluate it.

The question of how the Oslo participants define talent also matters because of the argument that emerges repeatedly throughout the interview: that to prioritise gender balance is to deprioritise talent. Three implications of this common claim stand out. On one level, the subtext is that on average, fewer women than men possess talent in DJing. On another, the argument rests on a common (mis)understanding of the idea of talent-one that is not specific to music participation, but that is central to it: namely that it can be evaluated objectively. As the conversation between Oslo participants highlighted, talent is not an objective or measurable variable, and sociologists of the arts and music have made it their business to problematise this and similar notions that elevate art above other types of work (Becker 1982; Frith 1996, 2011). Understandings of talent in DJ cultures are, on the contrary, often based on personal impressions. These can vary dramatically as DJing involves a wide choice of technologies and techniques. Talent is therefore too contingent a concept to be "threatened" by gender equality policies.

Creativity —an idea that Frith (2011) aptly describes in Durkheimian terms as "a social fact" - should be similarly scrutinised, because it dictates contemporary cultural policies in many western countries (Frith 2011: 62; Reitsamer 2011: 30-2; Conor et al. 2015: 3-5). Like talent, creativity has many possible meanings, depending on whether artists (and what kinds of artists), cultural policy makers or market investors are defining it (Frith 2011: 63; Reitsamer 2011:39). Creativity in the business world can even equate to productivity-Google and other Silicon Valley industry models are cases in point—or utility (Reitsamer 2011:39). In music, including in DJ worlds, the idea is still Romantic-it demands newness, novelty and "freedom", while being codependent with the contemporary market economy (Frith 2011: 63, 68-9; Reitsamer 2011: 40). This codependence is dysfunctional: music requires the work of many actors to materialise, yet it is referred to in musical worlds in old terms of distinction between expressive capacities of individual artists and the "craft" of performing music for money (Becker 1982; Frith 2011: 70). ${ }^{22}$

A helpful parallel to the argument about talent is how the artistic "genius" in western musical histories and canons has always been gendered. In one example, philosopher Christine Battersby has accounted for the way that genius across the arts has been framed 
as the exclusive property of men, all the while possessing "feminine" qualities (1989: 3-11). Battersby's (1989) critique of "genius" is to focus on challenging its gendering:

The concept of genius is too deeply embedded in our conceptual scheme for us to solve our aesthetic problems by simply amputating all talk of genius, or by refusing to evaluate individual authors and artists. Before we can fundamentally revalue the old aesthetic values, the concept of genius has to be appropriated by feminists, and made to work for us (15).

I would also add to this a reminder that genius is a historically-specific paradigm-critiquing the concept is far from "amputating all talk" of it (Battersby 1989: 15). In this sense, I understand the gendering of genius to be just one part of this larger paradigm that has many potential grounds for critique. ${ }^{23}$

Overall, talent, creativity and genius are concepts that reflect Romantic values of artistry. Although the Romantic artist - the DJ, in this article-seems in some ways to be at odds with the discipline that is required of the neoliberal female subject, the primacy of the individual is not only common, but central to Romanticism and neoliberalism. As the group interview shows, DJs are embodiments of this blend, with expectations of being both "entrepreneurial" and "free" at once (Reitsamer 2011: 36-40; see also Frith 2011: 63). What is more, in articulating a "grammar of individualism" (Gill 2007: 153), the above participants deny the realities and effects of systematic gender discrimination. ${ }^{24}$

\section{CONCLUSION}

When it comes to gender equality, Norway is a nation with relative advantage. This is most visible in its legal frameworks, where gender parity-albeit on problematic, binary models of gender-is a key goal. In this article, I have outlined some key moments when governments formalised these ideas: women's rights to vote, access to university education and unionisation in the early $20^{\text {th }}$ century; the Gender Equality Act in 1978; affirmative action to hire more women on corporate boards in the early 2000s; and the gender selfdetermination law in 2016. However, there is a substantial difference between the equality achieved in public and private sectors respectively. The casual workforce that encompasses DJ and many other musicians' work is a stark example; it is challenging to monitor the implementation of inclusive practices in such fluid and unpredictable environments. Consequently, victims of informal discrimination in these settings are unsurprisingly the same people for whom the equality policies have been necessary in the first place-for example, people who are not male and not white.

Moreover, while various media have constituted platforms for these marginalised voices, the counter-reactions coming from cultural intermediaries such as Hans and Lars have been at least as audible. Specifically, Hans and Lars argue that they are being misunderstood: that they do not discriminate against anyone, but that women tend to be less interested in the "craftsmanship" of DJing, less involved with the "nerding out" cultures of record collecting and less active at informal networking than men. This is often coupled with the assertion 
that intuitive understandings of dance floor dynamics and other markers of quality have nothing to do with gender. The implication is that imbalances are coincidental by-products of the demographics of the people who happen to be performing well. Yet as I have shown in this article, these criteria are all profoundly gendered. Indeed, as Gill observes, "the notion that all our practices are freely chosen is central to postfeminist discourses, which present women as autonomous agents no longer constrained by any inequalities or power imbalances whatsoever" (2007: 153). Together, these counter-reactions make up the widespread paradigm of individualism, of which postfeminist and meritocratic philosophies are a part.

I have previously argued that popular discourses on utopianism in dance music culture leave little room for addressing problematic gender dynamics in these scenes (Gadir 2016). Specifically, these perspectives overlook the many spaces that reiterate the same types of discrimination that occur off the dance floor. The perspectives that participants presented in conversation with me after Musikkfest are compatible with this idea. As such, claims that some dance floors are free of discrimination while not acknowledging that other dance floors are not, are comparable with postfeminist ideas that gender inequality is a problem of the past. Although the two political positions are contrasting, both utopian and postfeminist perspectives of dance music cultures ultimately avoid and deny the hostility and violence that takes place because of gender-behind DJ booths, on dance floors and in-between gigs.

Finally, the Musikkfest case shows DJ and dance music culture to be an art world, where artistic value is idealised to the point that it nullifies the value of anything else. In this case, the music, through the skill of the DJ, is presented as more important than people's lived experiences of systemic inequalities. This is an unsettling demonstration of what postfeminism, in its omnipresence, actually embodies: a collection of defenses used by those in decision-making or power positions-and internalised by those who are not-in industries where women are significant, active and audible, but where they nevertheless remain unequal participants.

\section{ACKNOWLEDGEMENTS}

Thanks are due to Tom Western for his meticulous interview transcriptions, and to the DJs and booking agents in Oslo for their time and openness in interviews. I would also like to acknowledge the help of my colleagues in the Department of Musicology at the University of Oslo, for guiding me toward relevant local media and information sources, and for giving me feedback on drafts of this article. Thank you to Åshild Watne for helping me with interpretation of the Norwegian language in government sources, and to Astrid Kvalbein for both her leads to historic media sources on music and gender and inspiring conversations. 


\section{NOTES}

1 Lars, interview with the author (Oslo), 31 October 2016.

2 All interviewees were given pseudonyms for this article.

3 Definitions of postfeminism (or post-feminism) vary. Catherine Malabou's definition points to gender and queer theory's anti-essentialist and dualist stance on gender (2011: 1). However, I use "postfeminism" (one word, no hyphen) as it is used to refer to a kind of anti-feminism in media and culture.

4 Far from being simple, "gender equality" is a set of multifaceted, interrelated ideas. What gender equality means for different communities depends on how these communities define it, and what values they hold. Some ways of understanding gender equality allow it to be measured, whereas others focus on less quantifiable notions such as culture, knowledge, power, opportunity and individual upward mobility (Inglehart and Norris 2003; Teigen and Wängnerud 2009: 21-3).

5 For analyses that challenge the popular discourse on gender equality in the Nordic countries, see also Teigen (2011) and Åsebø (2016).

6 See, for example, Fikentscher (2000) and Lawrence (2003).

7 Putting the idea that all people have equal citizenship status into practice is historically not a given. Australia (looking toward Britain and the United States) was among the countries that adopted temporary postwar social democratic models in mid-century, for instance, with a policy of so-called "full employment" (Macintyre 1986: 7; Coombs 1994: 6; Macintyre 1999, Harris 2001: 11-14). Yet among other groups, white Australian women were excluded from this-expected to depart from their wartime work and fulfil family and domestic duties (Harris 2001: 14). Other groups were excluded in various ways, despite the promotion of this period as a golden age, such as the lack of any benefits for long-term unemployed Indigenous people (Kewley in Harris 2001: 14).

8 This is the case for DJs at the local level; international, touring DJs have managers, lawyers and insurance. Moreover, although some events operate "off the radar", such as in illegal spaces and at unlicenced events, many do take place within publicly regulated spaces such as night clubs and within publicly regulated events that work within legal frameworks.

9 This interview was conducted as part of my current research project (2015-18) on women DJs from around the world.

10 Hartline notes that on the one hand, the new legislation has been celebrated as forward thinking, and has been understandably embraced by those who have transitioned from female to male, or male to female. However, it is still a form of discrimination against those who identify as genderqueer or gender nonconforming, who still have to choose between "female" or "male" (Hartline, forthcoming). In addition, there are still deep systemic issues that remain unresolved, such as the tendency to "diagnose" gender nonconformity as a medical condition by public health services (see van der Ros 2017: 129-30; Hartline, forthcoming: 3-4).

11 My own research on gender, for example, has been cited on the NRK's "Culture News" radio program (Kulturnytt 2016). 
12 The second group had been booked for Musikkfest gigs but had to turn them down. This was part of the defense of the booking agents when they were accused of only booking four women - that some had turned down their offers. Furthermore, the additional two DJs had not been exposed to the public debate, while the other five interviewees contributed to it directly. As a result, most of the conversation with the additional group steered away from Musikkfest to general DJing experiences, and I have not included these here.

Group interviews are more complex, and harder to organise than one-on-one interviews. In introducing more people to a conversation, one person's articulations of an issue necessarily affect how others speak about it, with the resulting narrative being shaped by dynamics of a specific group. However, unstructured one-on-one interviews are also necessarily unsystematic, and always informed by the presence of the interviewer. In conducting group interviews, I match the untidy, performative character of debates between DJs and booking agents online. This includes, in the case of the interview in this article, some participants coming and going at different points, while the conversation continues. Moreover, the group interview is a means of helping interviewees to feel socially "cushioned" and supported by others, in order that they feel safe to articulate what they wish to. This is especially relevant in this case, where each side of the debate has felt attacked by the other for their differing perspectives. Finally, having a group conversation is a means to ensure the inclusion of the male booking agents in the conversation. The stranger status that I held before the interview was mitigated by my offer of an informal group conversation with personal and professional acquaintances (the DJs). As an interviewer and moderator, my interventions are the same as in any one-on-one interview: starting with a broad opening question; and interjecting only if a point of particular interest is worth following up. The primary difference is that there are more than two voices, and the conversation steers itself with less help from the interviewer.

13 This is not a view exclusive to this community. The idea that merit is compromised when a gender balance is prioritised is prevalent across the arts in Norway, including the visual arts (Åsebø 2016). Additionally, this was the discourse that prevailed in objections to gender equality policies for corporate boards (Dowling 2010; Teigen 2011).

14 The latter occurred most notably when the two male booking agents of the group had departed.

15 It is understandable that Dani articulates such frustration with the gender critiques on the one hand and agreement with them on the other. As one of the only four women chosen for this festival, she sought acknowledgement of her ability to "make it" on the basis of her skills and not her gender. Yet this indicates her exceptional resilience in an aggressively competitive, maledominated milieu, rather than illustrating an equal and fair working environment for all genders.

16 This statement also hinges on gendered assumptions. It disregards the masculine connotations of the "small-time gangster" and the question of whether it is as socially acceptable for women to "hustle" as for men.

17 See Will Straw (1997) for a compelling analysis of the strong gendering of "nerd" cultures with reference to record collecting.

18 The reality of this visual foregrounding stands in opposition to the traditional (and often idealised) role of the DJ—-to play music that people dance to. In this way, her job should differ from that of musical performers such as guitarists or singers, as it does not matter whether she is seen. 
19 In an interview conducted by Farrugia (2010: 90), techno producer Kate Simko shows a similar pattern.

20 This last passage is indicative of how the enduring paradigm of sound production and reproduction technologies' gendering is internalised by all genders, despite women's active involvement in the development of electronic musics. These ideas about women and technology are also replicated in representations in "the canon" of written texts about electronic and dance musics (Brewster and Broughton 1999; Shapiro 2000), though these have important exceptions (Butler 2006; Dowling 2010; Farrugia 2012; Gavanas and Reitsamer 2013). However, there are aspects of the cultural histories of these sound technologies that have contributed to contemporary understandings of their gendering (Rodgers 2010: 6-8; Farrugia 2012: 8-10, 21-3).

21 This is rarely acknowledged openly, presumably due to impressions of professionalism, and more specifically that it would contradict their claims to choosing DJs on the basis of skill alone.

22 Even in this sociological conceptualisation, the actor who seeks to be defined as creative is gendered male; all of the examples of music industry participants that Frith cites are men.

23 I take my cue here from Frith's aforementioned approach to creativity (2011).

24 For accounts that show the range and nature of this discrimination, see Gadir (2016).

\section{REFERENCES}

Asker, Cecile. 2010. "Balansekunst”. Aftenposten. 4 August: 9.

Battersby, Christine. 1989. Gender and Genius: Towards a Feminist Aesthetics. Bloomington: Indiana University Press.

Becker, Howard, S. 1982. Art Worlds. Berkeley: University of California Press.

Bjørhovde, Hilde. "Musikkfest Oslo: Karnevalsparade og gratis konsertfest hele lørdag”. Aftenposten. 5 June 2015. <http://www.aftenposten.no/osloby/byliv/Musikkfest-OsloKarnevalsparade-og-gratis-konsertfest-hele-lordag-38268b.html > (accessed 2 April 2017).

Brewster, Bill and Frank Broughton. 1999. Last Night a DJ Saved My Life: The History of the Disc Jockey. New York: Grove Press.

Brooks, Ann. 1997. Postfeminisms: Feminism, Cultural Theory and Cultural Forms. London and New York: Routledge.

Butler, Judith. 2008. "Sexual Politics, Torture, and Secular Time”. The British Journal of Sociology 59(1): 1-23. <http://dx.doi.org/10.1111/j.1468-4446.2007.00176.x >.

Butler, Mark J. 2006. Unlocking the Groove: Rhythm, Meter, and Musical Design in Electronic Dance Music. Bloomington: Indiana University Press.

Coombs, Herbert Cole. 1994. From Curtain to Keating - the 1945 and 1994 White Papers on Employment: A Better Environment for Human and Economic Diversity? North Australia Research Unit. Darwin: Australian National University.

Conor, Bridget, Rosalind Gill and Stephanie Taylor. 2015. "Gender and Creative Labour". The Sociological Review 63(S1): 1-22. <http://dx.doi.org/10.1111/1467-954X.12237>.

Dagbladet. 1929. "Ellen Gleditsch hjemme igjen: 500 dollars til stipendier for kvinner som vil arbeide videnskapelig”. 13 May: 1-2. 
Dahlerup, Drude. 2011. “Women in Nordic Politics - A Continuing Success Story?”. In Gender and Power in the Nordic Countries, ed. Kirsti Niskanen, 59-86. Oslo: NIKK.

Dowling, Siobhán. “Women on Board: Norway's Experience Shows Compulsory Quotas Work”. Spiegel Online. 8 July 2010:<http://www.spiegel.de/international/business/women-on-boardnorway-s-experience-shows-compulsory-quotas-work-a-705209.html > (accessed 26 November 2016).

The Economist. “The Best-And Worst_Places to be a Working Woman”. The Economist. 3 May 2016. <http://www.economist.com/blogs/graphicdetail/2016/03/daily-chart-0 > (accessed 15 November 2016).

Farrugia, Rebekah. 2012. Beyond the Dance Floor: Female DJs, Technology, and Dance Music Cultures. Chicago: Intellect.

- — - 2010. “'Let's Have At It!': Conversations with EDM Producers Kate Simko and DJ Denise". Dancecult: Journal of Electronic Dance Music Culture 1(2): 87-93. $<$ https://dj.dancecult.net/index.php/dancecult/article/view/290 $>$.

Fearnley, Marie (Mais). 1930. “Den moderne Eva: Borghild Langaard tilbake-hun åpner sangskole til høsten”. Dagbladet. 5 August.

Fikentscher, K. 2000. You Better Work! A Study of Underground Dance Music in New York City. Hanover: Wesleyan University Press.

Frith, Simon. 2011. "Creativity as a Social Fact". In Musical Imaginations: Multidisciplinary Perspectives on Creativity, Performance and Perception, ed. David Hargreaves, Dorothy Miell and Raymond MacDonald, 62-72. Oxford: Oxford University Press.

- _ - 1996. Performing Rites: On the Value of Popular Music. Cambridge, Massachusetts: Harvard University Press.

Furuseth, Karima. “47 artister, fire kvinner-her er 8 kvinnelige DJs Musikkfest Oslo KUNNE ha booket". NattઐDag. 24 May 2016. < http://www.nattogdag.no/2016/05/musikkfest-osloskjev-fordeling $>$ (accessed 15 November 2016).

Gadir, Tami. 2017. "I Don't Play Girly House Music: Women, Sonic Stereotyping and the Dancing DJ". In The Routledge Research Companion to Popular Music and Gender, ed. Stan Hawkins, 196-210. London: Routledge.

Gadir, Tami. 2016. "Resistance or Reiteration: Rethinking Gender in DJ Cultures". Contemporary Music Review 35(1): 115-29. <http://dx.doi.org/10.1080/07494467.2016.1176767>.

Gavanas, Anna and Rosa Reitsamer. 2013. "DJ Technologies, Social Networks and Gendered Trajectories in European DJ Cultures". In DJ Culture in the Mix: Power, Technology and Social Change in Electronic Dance Music, ed. Bernardo Alexander Attias, Anna Gavanas and Hillegonda C. Rietveld, 51-78. New York: Bloomsbury.

Gender in Norway. 2016. "National Legislation”. Gender in Norway. < http://www.gender.no/Legislation/National legislation> (accessed 15 November 2016).

Gill, Rosalind. 2016. "Post-Postfeminism?: New Feminist Visibilities in Postfeminist Times". Feminist Media Studies 16(4): 610-30. <http://dx.doi.org/10.1080/14680777.2016.1193293 >.

- - - 2007. "Postfeminist Media Culture: Elements of a Sensibility". European Journal of Cultural Studies 10(2): 147-66. < http://dx.doi.org/10.1177/1367549407075898>. 
Government.no. 2007. "The Act Relating to Gender Equality": <https://www.regjeringen.no/en/ dokumenter/the-act-relating-to-gender-equality-the-/id454568/> (accessed 15 November 2016).

Hambrick, David Z. and Elliot M. Tucker-Drob. 2014. “The Genetics of Music Accomplishment: Evidence for Gene-Environment Correlation and Interaction". Psychonomic Bulletin and Review 22: 112-20. <http://dx.doi.org/10.3758/s13423-014-0671-9>.

Harris, Patricia. 2001. "From Relief to Mutual Obligation: Welfare Rationalities and Unemployment in $20^{\text {th }}$ Century Australia". Journal of Sociology, 37(1): 5-26. $<$ http://dx.doi.org/10.1177/144078301128756175>.

Hartline, France Rose. Forthcoming. "(Trans)Gender Outlaws? A Critical Analysis of Norway's 2016 Gender Self-Determination Law”. Dutch Journal for Gender Studies.

Helding, Lynn. 2011. "Innate Talent: Myth or Reality? Mindful Voice”. Journal of Singing 67(4): 451-8.

Hubbell, Diana. "Meet Nakadia, the DJ from Rural Thailand Who is Underground Techno's Rising Star”. Thump. 4 February 2016. < http://thump.vice.com/en_us/article/nakadiamungphanklang-interview-thailand-dj-sven-vath> (accessed 4 February 2016).

Høyre. 2017. Høyre's Parliamentary Election Manifesto for 2017-2021. Adopted at Høyres National Convention. 9-12 March. < https://hoyre.no/om-hoyre/partiet/information-in-english/> (accessed 20 September 2017).

Howe, Michael J. A., Jane W. Davidson and John A. Sloboda. 1998. "Innate Talents: Reality or Myth?". Behavioral and Brain Sciences 21: 399-442. $<$ http://dx.doi.org/10.1017/S0140525X9800123X>.

Inglehart, Ronald and Pippa Norris. 2003. Rising Tide: Gender Equality and Cultural Change Around the World. Cambridge: Cambridge University Press.

Kvalbein, Astrid. 2013. "Menn jubilerer for full musikk”. Aftenposten. 27 April: 7.

Lal, Kish. "Meet the Djs Challenging Melbourne's Blokey Club Scene". Inthemix. 6 July 2016, $<$ http://inthemix.junkee.com/meet-the-new-djs-challenging-melbournes-blokey-clubscene/> (accessed 6 July 2016).

Larsen, Gunnar (Kollskegg). 1927. "Oslo Kvinneparti Blev Stiftet Igår”. Dagbladet. 7 December. Lawrence, Tim. 2003. Love Saves the Day: A History of American Dance Music Culture, 19701979. Durham and London: Duke University Press.

Leonard, Marion. 2007. Gender in the Music Industry: Rock, Discourse and Girl Power. Aldershot and Burlington: Ashgate.

Lindbæk, Lise. 1936. "En ny tids kvinnesak: Inntrykk fra Yrkes kvinners sommerleir på Hundorp”. Urd 36: 1126-7.

Loben, Carl. "Who Are the Women Pioneers of Dance Music?". Huffpost Entertainment, United Kingdom. 28 April 2016. <http://www.huffingtonpost.co.uk/carl-loben/women-pioneers-ofdance-music b 9794186.html $>$ (accessed 28 April 2016).

Lund, Joachim. 2012. “Mer østrogen, takk!”. Aftenposten. 24 March: 6.

- — - 2011. "Her kommer guttemusikken". Aftenposten. 4 June: 12.

Marcus, Gary. 2012. Guitar Hero: The New Musician and the Science of Learning. New York: The Penguin Press. 
Malabou, Catherine. 2011. Changing Difference: The Feminine and the Question of Philosophy. Cambridge: Polity.

Matos, Michaelangelo. “Nightclubbing: Your Sisters' House”. Red Bull Music Academy Daily. 17 February 2015. < http://daily.redbullmusicacademy.com/2015/02/nightclubbing-your-sistershouse $>$ (accessed 17 February 2016).

- _ - “The Techno Feminists Next Door". NPR Music: The Record. 6 November 2015. $<$ http://www.npr.org/sections/therecord/2015/11/06/454946162/the-techno-feministsnext-door $>$ (accessed 6 November 2016).

Macintyre, Clement. 1999. "From Entitlement to Obligation in the Australian Welfare State". Australian

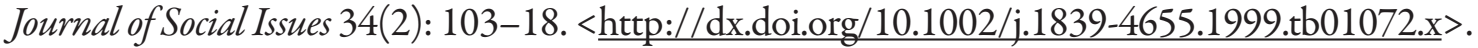

Macintyre, Stuart. 1986. “The Short History of Social Democracy in Australia”. Thesis Eleven 15(1): 3-14. <http://dx.doi.org/10.1177/072551368601500101>.

McRobbie, Angela. 2009. The Aftermath of Feminism: Gender, Culture and Social Change. Los Angeles: Sage.

— - _ 2004. "Post-Feminism and Popular Culture". Feminist Media Studies 4(3): 255-64. <http://dx.doi.org/10.1080/1468077042000309937>.

Mepschen, Paul, Jan Willem Duyvendak and Evelien H. Tonkens. 2010. "Sexual Politics, Orientalism and Multicultural Citizenship in the Netherlands”. Sociology 44(5): 962-79. < http://dx.doi.org/10.1177/0038038510375740>.

Ministry of Health and Care Services (Det Kongelige Helse-og Omsorgsdepartment). 20152016. Prop. 74 L: Proposisjon til Stortinget (forlsag til lovvedtak): Lov om endring av juridisk kjønn. <https://www.regjeringen.no/no/dokumenter/prop.-74-1-20152016/id2479716/> (accessed 20 September 2017).

Mitchell, Aurora. "9 All-Female DJ Collectives You Need To Know Right Now”. Fader. 17 February 2015. <http://www.thefader.com/2016/02/17/female-dj-crews-discwoman-sistermahoyo-tgaf $>$ (accessed 17 February 2016).

Modleski, Tania. 1991. Feminism Without Women: Culture and Criticism in a "Postfeminist" Age. New York and London: Routledge.

Mosing, Miriam A., Guy Madison, Nancy L. Pedersen, Ralf Kuja-Halkola and Fredrik Ullén. 2014. "Practice Does Not Make Perfect: No Causal Effect of Music Practice on Music Ability". Psychological Science 25(9): 1795-803. < http://dx.doi.org/10.1177/0956797614541990>.

Niskanen, Kirsti. 2011. "Gender and Power in the Nordic Countries: A Comparative Perspective”. In Gender and Power in the Nordic Countries, ed. Kirsti Niskanen, 11-58. Oslo: NIKK.

NRK. “Kvinnelige DJar vert diskriminerte”. NRK Radio Kulturnytt. 7 November 2016.

Reitsamer, Rosa. 2011. “The DIY Careers of Techno and Drum 'n' Bass DJs in Vienna”. Dancecult 3(1): 28-43. <https://dj.dancecult.net/index.php/dancecult/article/view/315>.

Resident Advisor. “Between the Beats: The Black Madonna”. Resident Advisor. 11 August 2016. <https://www.residentadvisor.net/features/2793> (accessed 11 August 2016).

Rodgers, Tara. 2010. Pink Noises: Women on Electronic Music and Sound. Durham: Duke University Press. 
Shapiro, Peter, ed. 2000. Modulations: A History of Electronic Music. New York: Caipirinha Productions.

Stenhamar, Halldis (Hast). 1932. "Kvinnelige studenter gjennem 50 år — jubileumsboken er ferdig". Dagbladet. 25 February: 1, 3.

Stortinget. 2016a. "Article 98". The Constitution, as Laid Down on 17 May 1814 by the Constituent Assembly at Eidsvoll and Subsequently Amended, Most Recently in May 2016. <https://www.stortinget.no/globalassets/pdf/english/constitutionenglish.pdf> (accessed 20 September 2017).

Stortinget. “Komiteens tilråding om endring av juridisk kjønn”. Stortinget. 30 May 2016. $<$ https://www.stortinget.no/no/Saker-og-publikasjoner/Saker/Sak/Voteringsoversikt/?p=64 488\&dnid=1 - id=7357\&view =vote-text $>$ (accessed 15 November 2016).

Straw, W. 1997. "Sizing Up Record Collections: Gender and Connoisseurship in Rock Music Culture". In Sexing the Groove: Popular Music and Gender, ed. Sheila Whiteley, 3-16. London and New York: Routledge.

Stetka, Bret. "What Do Great Musicians Have in Common? DNA". Scientific American. 5 August 2014. <https://www.scientificamerican.com/article/what-do-great-musicians-have-in-common-dna/> (accessed 19 September 2017).

Svendsen, Stine H. Bang. 2017. “The Cultural Politics of Sex Education in the Nordics”. In The Palgrave Handbook of Sexuality Education, ed. Louisa Allen and Mary Lou Rasmussen, 137-56. London: Palgrave Macmillan.

Teigen, Mari. 2011. "Gender Quotas on Corporate Boards”. In Gender and Power in the Nordic Countries, ed. Kirsti Niskanen, 87-109. Oslo: NIKK.

Teigen, Mari and Wängnerud, Lena. 2009. “Tracing Gender Equality Cultures:

Elite Perceptions of Gender Equality in Norway and Sweden”. Politics \& Gender (5): 21-44. <http://dx.doi.org/10.1017/S1743923X09000026>.

Thommessen, Olemic. 2015-2016. Lovvedtak 71 (Første gangs behandling av lovvedtak). 30 May.

Thornton, Sarah. 1995. Club Cultures: Music, Media and Subcultural Capital. Cambridge: Polity Press.

Thump. “Three Female Canadian DJs Discuss Gender Inequality in the Dance World". 13 January 2016. <https://thump.vice.com/en us/article/three-female-canadian-djs-discuss-genderinequality-in-the-dance-world $>$ (accessed 13 January 2016).

Weinberger, Norman M. 2001. “Musical Talent: Real or a Myth?”. MuSICA Research Notes 8(2). <http://www.musica.uci.edu/mrn/V8I2S01.html - real> (accessed 19 September 2017).

Weiner, Sophie. "Can Teaching Young Women to DJ and Produce Solve Gender Equality in Electronic Music?”. Thump: Women in Dance Music. 26 February 2016. < http://thump.vice. com/en_us/article/can-teaching-young-women-to-dj-and-produce-solve-gender-inequalityin-electronic-music> (accessed 26 February 2016).

Woldsdal, Nicolay. “Øya får internasjonal oppmerksomhet for sin line-up”. Dagbladet. 7 July 2015. <http://www.dagbladet.no/2015/07/07/kultur/oya/musikk/festival/konsert/40013709/> (accessed 5 December 2016).

Åsebø, Sigrun. 2016. “Representation of Gender and/in Visual Culture.” Lecture. Sundvolden (Norway): Gender National Research School General Course. 